\title{
Sociolinguistics of translation
}

\author{
KINGA KLAUDY \\ ELTE Fordító- és Tolmácsképző Központ, Budapest, Múzeum krt. 4/F, H-1088 \\ E-mail: kklaudy@ludens.elte.hu
}

(Received: 1 September 2006; accepted: 16 October 2006)

\begin{abstract}
The paper describes how sociolinguistics, revealing the relationship between language and society independently of translation, provides scientifically well-founded descriptions of the relationship between the source language and source language society, and the target language and the target language society, and might thus contribute to exploring the objective rules behind the translators' decisions.

Keywords: pragmatic adaptation, translation of dialects, translation of realia, untranslatability, intercultural translation policy
\end{abstract}

\section{The concept of pragmatic adaptation}

The history of thinking about translation has never failed to recognise the social importance of translation. In the history of translation in Hungary, especially in the 18th century (in the works of János Batsányi, Ferenc Kazinczy, György Bessenyei), thoughts on the social relevance of translation gained much more importance than the linguistic exploration of translation (on the Hungarian tradition see Radó in Baker 1998: 448-453).

What is called in today's modern terminology pragmatic adaptation (Neubert 1968), i. e. the adaptation of the translated work to the needs of the target language audience, has never been better accomplished than in the case of András Dugonics in 1807, who placed Voltaire's Zadig into a Hungarian context under the title Cserei, egy honvári herceg, into 10th-century Hungary, the era of Taksony vezér (i. e. Taksony chief) (Dugonics 1807, 1975).

\section{The reproduction of individual speech styles}

In the case of translating literary pieces, it is an important problem to render the individual (social or regional) speech style of the characters. This particular translation problem is related to the problem of the vertical and horizontal stratifi- 
cation of languages, i. e. since it concerns the process of translation, to the problem of the differing horizontal and vertical stratification of the two languages.

In Aristophanes's comedy, the Lysistrate, the Doric dialect of the Spartans is the sign of provinciality in contrast to the sophisticated Attic dialect of the Athenians. The Spartan envoy speaking a Doric dialect speaks a Scottish dialect in the English translation and a southern one in the American version, whereas in the Nigerian translation he speaks a Nigerian pidgin, commanding lower prestige (Šveicer 1988). It is worth looking at a few sentences uttered by the Spartan envoy and compare them with the Athenian counselor's speech in János Arany's Hungarian translation. Since it is a 19th-century translation, it is not only the Spartan envoy's speech that differs from the speech of the Athenian counselor in it, but the speech of all of the characters in the comedy differs from currently spoken Hungarian. However, the differing characteristics of the Spartan envoy's speech from that of the Athenian counselor, for example the distortion of words (aszánai instead of athéni), the use of vernacular forms (gyüvök instead of jövök), clipping the endings of words (Spártábó' instead of Spártából, ne bomó instead of ne bomolj), and frequent outbursts of temper ('stenuccse, Kastor uccseg, Zeus uccse), provide clear evidence for present-day Hungarian readers he is speaking a low prestige dialect.

Making the Spartan envoy speak is a relatively easy task for the translator. No matter what century and what language it is, when translating Aristophanes' comedy, the translator only has to indicate provinciality in contrast to literary linguistic norm prevalent in the given century and language.

\section{The reproduction of regional dialects}

Imre Makai had a considerably more difficult task when translating Šolohov's Silent Don. He had to find the Hungarian regional equivalents of the regional words and dialect used by proud, brave, and free Cossacks. He could have chosen to do the same as the translator of the German edition, who did not even try to hint at the Don dialect, while Makai claimed that it would have been “... simply forgery: it would have falsified its Cossack and popular nature, its Don-like tone and atmosphere." (Makai 1981: 575)

Just imagine what an extraordinary task it is for a translator to find a Hungarian dialect that can reflect the novel's "Don-like atmosphere". Imre Makai offers a remarkable sociolinguistic explanation to why he finally opted for the dialect of Hajdúság (a county in Hungary):

... the two ethnic communities resemble each other both in terms of their evolution and their history. Originally they were homeless peasants and outlaws who banded together and, holding one hand on the plough tail and the other on the hilt of the sword, they became soldier-peasants. The sole difference between them was that the Cossacks first fought against the Czar, and only then did they become his servants, while the Heyducks first served the Austrian Emperor and then joined the army of the Transsylvanian Prince Bocskai. The important point is that their life styles were similar. This is where the similarity of their thinking, and consequently language, originates from: both the Cossacks and the Heyducks are characterised by a harsh and sharp-witted style, lacking the signs of sentimentalism or flourish, and crackling dialogues. (Makai 1981: 574. translated by Krisztina Károly)

\section{The reproduction of social dialects}


Abundant examples of the vertical stratification of the two languages can be observed in the Hungarian translations of Russian classics. Civil servants in the lower ranks of the rigid, 14-class social ladder of Russian officialdom often use the "s" sound that originated from the words gosudar and sudar 'sir' to express respect. The servile fawning and abjectness expressed by this linguistic element in Russian is often lost in the Hungarian translations; not only because the Hungarian vocabulary equivalent $u r(a m)$ cannot be abbreviated to just one sound, but also because in Hungarian society the relations of sub- and super-ordination were different and so were, consequently, the linguistic expressions corresponding to them. Ferenc Papp (1979) cites the abbreviation tekintetes-téns 'honourable' as a formal analogy, and functionally compares the use of the Russian particle " $s$ " to the Hungarian kérlek/kérem alássan 'I humbly beg to'. Both of them mark a very rare and socially strongly restricted language use in Hungarian. It is also mentioned by Papp that the Russian particle " $s$ " expressing the relations of social suband super-ordination receives an interesting role in Dostoyevskiy's novel, Crime and Punishment, where the pretended servility of the magistrate playing a teasing game with Raskolnikov is expressed through the constant use of the particle "s". This inversion of the relations of social sub- and super-ordination is crucial in this scene, but the translator could only reflect it if Hungarian also had a particle to express servility, which the translator could attach to the words of the magistrate, thus reproducing the awkwardness and the ambiguity of the situation.

\section{The translation of lexis without equivalence}

Another area where translation theory can greatly benefit from sociolinguistics is the translation of what is usually referred to as "lexis without equivalence", or, to use another term, "realia". How can we translate the names of objects typically characteristic of a particular language community (meals, clothes, dishes, dances, etc.) into another language in which these objects do not exist (Vlakhov and Florin 1980) This question can be investigated on the surface level as a vocabulary difference, but it can also be looked at from a broader perspective, based on sociolinguistic research into language contacts (Weinreich 1966).

The theory of language contacts treats the activity of two language communities aimed at exploring each other's realia as a process, in which various social strata and groups (in earlier times mainly travellers and literary translators, while today mostly students, scientists and scholars, journalists, reporters, etc.) have different roles. This process of exploration and denotation between two language communities takes place in different ways, depending on geographical distance and length of the contact situation: thus, e.g., Hungarian and German have been in permanent contact for several centuries, and Hungarian and Russian came into contact in the second half of the 20th century, while Hungarian and Japanese are geographically remote from each other..

The exploring-denoting activity is also different in the case of language communities on the same social-economic level, where it is a two-way process, and in the case of language communities with differing economic-social levels, where it is a one-way process. Regarding Hungarian, Endre Lendvai (1986) was a pioneer in this field, who investigated the Hungarian equivalents of typically Russian 
realia placed in a broader social context. The word gimnastyorka ('a jacket-like military shirt with a high collar', cf. Bakos 1994: 284), a commonly known word in the 1950s in Hungary, does not mean anything to young people in the 1980s. In Endre Lendvai's survey (1984-1985), students gave the following answers when asked about the meaning of the word gimnasztyorka: gymnast, gym shirt, P. E. class, secondary school student (Hung. gimnazista), morning gymnastics/work out.

\section{Translatability and untranslatability}

The socio-linguistic approach is especially important in investigating the problem of translatability and untranslatability (Mounin 1963). The vacuity of the agruments put forward to support the idea of untranslatability is best shown by the tremendous amount of translations produced all over the world, refuting the thesis of untranslatability day by day, and yet every book on translation theory contains a section devoted to this problem.

Mounin, the eminent French translation scholar ingeniously refutes the claim that the differences above would reflect different views of the world:

$\ldots$ if within the same language one conducts several similar analyses, then it may be concluded that speakers even of the same language gain their experience of the world at different levels. The fact that this is reflected in the structure of lexis does not mean that we are faced with different world views. At a place where the common Frenchman sees only snow, the French ski champion can distinguish between and name several types of snow, the same way as Lapps or Eskimos living in the distant Arctic... (Mounin 1963).

This obviously does not mean that the average Frenchman's world view differs from that of the French ski champion, or that the world view of the latter would be similar to that of the Lapps or Eskimos. It is more correct to say that all Eskimos come into contact with snow in one way or another, and thus the vocabulary related to snow becomes part of everyday speech, while in French it remains part of merely of the technical vocabulary used by a restricted number of people.

\section{Realia and untranslatability}

The other argument for untranslatability is the translation or the impossibility of the translation of "realia" mentioned above (names for objects used only by a particular group of people), since these, in fact, cannot be translated into the language of a community which does not know it.

If realia are simply translated into the target language, then the translation will make no sense without footnotes. If the translator tries to find some target language realia with a similar function and uses that instead, then the informative, culture-enriching function of translation is endangered, since realia contain abundant information about the culture, life style, habits, self-esteem, etc. of the given language community, and the aim of translation, sometimes, is precisely to reflect this information.

As mentioned before, it is one of the sociolinguistic disciplines that may help in resolving this dilemma. The theory of language contacts looks at the problem of the translation of realia not merely as a linguistic problem, but considers it as part of a process in which the two language communities in contact get to know each other's culture (and this process might not take place primarily through translation), and during this process both cultures accumulate knowledge about each other's realia. Simultaneously with 
the accumulation of knowledge, in fact, sometimes prior to it, the two cultures they might also develop an evaluative relationship regarding each other's realia. This is shown by the increasing prestige of the Russian words bolsevik 'bolshevik', sztahanovista 'Stakhanovite', kolhoz 'collective farm', kulák 'wealthy peasant', in Hungarian in the 1950s and their decreasing prestige nowadays.

When translating realia, translators consciously or intuitively take into consideration the knowledge-accumulating and evaluating activity of the target language society. Thus, the existence of realia does not support the theory of untranslatability, but rather the fact that to be able to translate them, i. e. find equivalences for them, one has to start out from the knowledge and evaluative relationship the target language society possesses about the given realia and not the actual source language norm. This is a sociolinguistic fact and it can be investigated with the research methods (e. g., questionnaires) of sociolinguistics.

\section{New challenges for the sociolinguistics of translation}

While translation scholars are peacefully exploring problems of translation caused by cultural differences, events in real life, such as the migration brought about by the opening of frontiers, forces practising translators and interpreters to mediate - in addition to mediating between languages - between cultures and social groups as well.

Wadensjö (1992) investigates the theoretical problems of community interpreting in situations where immigrants, i.e. not only linguistically but also socially defenseless people face trial. These people expect more of an interpreter than just simple linguistic mediation without sympathy, so interpreters working in the field need to receive special training. (Wadensjö 1992).

It was also "life" that gave the opportunity to Miriam Shlesinger in Tel Aviv to analyse the work of interpreters in court trials of war criminals to see what additional information needs to be mediated apart from linguistic meaning to ensure understanding at such a multilingual trial. Miriam Shlesinger's study is based on the State of Israel versus Demjanjuk case, tried in 1987-1988 in Jerusalem. The trial was conducted in six languages: English, German, Russian, Ukrainian, Yiddish, and Hebrew. Thirteen professional and one non-professional interpreters were employed, since they could not find an official interpreter in Ukrainian and Hebrew. Every form of interpretation was represented here: from consecutive and simultaneous interpreting to actually whispering in the ears. To ensure understanding among the participants of the multilingual trial, numerous pragmatic adaptations were necessary: the translation of even such seemingly problem-free phrases as for instance "the winter of 1986" caused difficulties:

... when an American attorney questioned an Israeli police man about the "winter of 1986", the former was referring the period beginning in November 1986 (by which time winter sets in the area where he lives) and lasting about April 1987, whereas the latter assumed this referred to the period beginning in January 1986 and lasting through March of the year, in line with Israeli climate. A rendering of "the winter of 1986" as "the winter of 1985" would have prevented the misunderstanding which the interpreter, deterred by the stricture of "faithfulness" and "accuracy" in translation, refrained from exercising latitude in this case. (Shlesinger 1991: 149).

With the increase in the translation needs of international organisations and 
multinational companies, José Lambert (1993), forecasts a radical change in the relationship between culture and translation. In his view it is not correct to investigate cultural differences within the framework of translation studies, restricting them to the problem of translating meals, drinks, dances, types of money, etc., i. e. realia. He considers culture research to be the broader concept, of which translation studies forms a part. Translation should always be viewed within the total network of social-cultural norms, starting with finding out about the kinds of documents that international organisations, multinational firms, and international publishing companies translate and do not translate, continuing with the instructions, explicit or implicit, that they give to translators, and ending with the use they make of the translation (how widely they circulate it, etc.).

Contemporary research on "translation policy" examines how the international political and economic institutions are taking over the leading role of conventional cultural frameworks defined by national languages and frontiers to form an intercultural translation policy.

\section{References}

Arany J. (1862) 1975. Arany János Válogatott Müvei III. Prózai Müvek. Budapest (1862) 1975.

Baker M. 1998. (ed.) Encyclopedia of Translation Studies. London.

Bakos F. 1974. Idegen szavak és kifejezések szótára. Budapest.

Bart I., Rákos S. (eds.) 1981. A müforditás ma. Budapest.

Dugonics A. 1807. Cserei, egy honvári herceg. (Hungarian translation of Zadig by Voltaire.) Republished in 1975 in the series "Old Hungarian Literary Translations". Budapest.

Lambert J. 1993. The Cultural Component Reconsidered. In: Snell-Hornby M. et al. (eds.), 17-26.

Lendvai E. 1986. A , lefordithatatlan elem” megfeleltetési lehetöségei. Unpublished PhD disseration. Pécs: Janus Pannonius Tudományegyetem.

Makai I. 1981. Solohov. In: Bart I., Rákos S. (eds.), 566-581.

Mounin G. 1963. Les problèmes théoriques de la traduction. Paris.

Neubert A. 1968. Pragmatische Aspekte der Übersetzung: Beiheft II. zur Zeitschrift „,Fremdsprachen“. Leipzig.

Papp F. 1979. Könyv az orosz nyelvröl. Budapest.

Radó Gy. 1998. Hungarian Tradition. In: Baker M. (ed.) Encyclopedia of Translation Studies.

Shlesinger M. 1991. Interpreter Latitude vs. Due Process. Simultaneous and Consecutive Interpretation in Multilingual Trials. In: Tirkkonen-Condit, S.(ed.) Empirical Research in Translation and Intercultural Studies. Tübingen, 147-157.

Швейцер А. Д. 1988. Теория перевода (статус проблемы аспекты). Москва.

Snell-Hornby M. et al. (eds.) 1993. Translation Studies: An Interdiscipline. Papers from the Vienna Congress, Sept. 1992. Amsterdam.

Влахов С., Флорин С. 1980. Непереводимое в переводе. Москва.

Wadensjö C. 1992. Interpreting as interaction. On dialogue-interpreting in immigration hearings and medical encounters. Linköping.

Weinreich U. 1966. Languages in Contact: Findings and Problems. The Hague. 